\title{
PHANTOM TUMOR OF THE LUNG IN PATIENT WITH PNEUMONIA
}

\author{
Mulić Mersudin, ${ }^{1}$ Biljana Lazovic, ${ }^{2}$ Detanac S. Džemail, ${ }^{3}$ \\ Detanac A. Dženana, ${ }^{3}$ Milić Rade, ${ }^{4}$ Žugič Vladimir ${ }^{5}$ \\ ${ }^{1}$ State university Novi Pazar, Novi Pazar, Serbia \\ ${ }^{2}$ University clinical center "Zemun”, Belgrade, Pulmonary Ward, Serbia \\ ${ }^{3}$ General hospital Novi Pazar, Novi Pazar, Serbia \\ ${ }^{4}$ Military medical academy, Belgrade, Serbia \\ ${ }^{5}$ Clinic for lung disease, Clinical Center of Serbia, School of medicine, Belgrade, Serbia
}

Primljen/Received 10. 01. 2019. god.

Abstract: Introduction: Localized interlobar effusions in congestive heart failure (phantom or vanishing lung tumor/s) are infrequent, but widely recognized entities.

Case report: A 80-years-old woman affected by progressive dyspnea over the previous three months, with productive cough. She was treated hypertension and had a pace maker implanted due to bradycardia. Chest $\mathrm{X}$ ray has shown right side pneumonia with high positive inflammatory markers. After resolution of pneumonia, phantom tumor of the lung was revealed, which disappear with intensive loop diuretics.

Conclusions: The diagnosis of the phantom tumor ought to be pondered as a possibility in any patient with congestive heart failure and lung mass. The patient at hand featured no prior history of congestive heart failure, hence indicating that phantom tumor may occur in non-chronic heart failure patients. Albeid the reliable diagnosis of the phantom tumor through the utilization of imaging modalities in patients without congestive heart failure can be rather challenging, such possibility must be considered in a patient with a lung
Prihvaćen/Accepted 08. 03. 2019. god.

mass in the major fissure of the lungs. Due to accelerated expansion of the geriatric population and subsequent spread of the congestive heart failure, a rise in the incidence of vanishing tumors of the lung may be anticipated.

Key words: congestive heart failure, loop diuretics, vanishing tumor.

\section{INTRODUCTION}

Phantom or vanishing tumor is a common term for a localized transudative interlobar pleural fluid collection in congestive heart failure, predominantly on right side and in male population (1). Such term stems from its frequent resemblance to a tumor on the Chest X ray and due to its being prone to disappear following the proper management of heart failure (1). Localized interlobar effusions are relatively infrequent, yet hold enough significance to merit recognition.

\section{CASE REPORT}

A 80-years-old woman affected by progressive dyspnea over the previous three months, with producti-
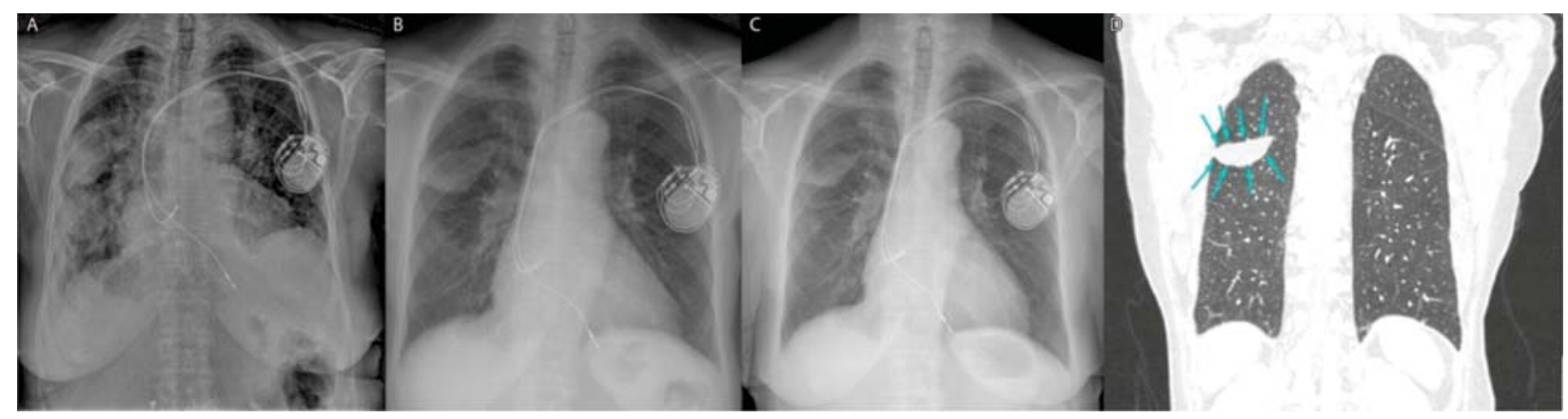

Figure 1. A. Chest radiograph showing rounded two $4 \times 3 \mathrm{~cm}$ opacity in middle and lower right lung and pace maker in left lung; $\boldsymbol{B}$. a homogeneous triangle of shadow in the middle pulmonary field on the right lung; $\boldsymbol{C}$. homogeneous shadow-effusion in little incisura; $\boldsymbol{D}$. verified effusion in the lung incisura on CT 
ve cough. She was treated hypertension and had a pace maker implanted due to bradycardia. Physical examination revealed cracles on the right lung. Chest $x$ ray confirmed right sided massive pneumonia, which indicated extremely careful access, since serious comorbidity which sometimes could be unpredicted $(2,3)$. Laboratory findings have shown high values of marker of acute phase of inflammation /SE, CRP, LE, Ne/. Triple antibiotics therapy was introduced according to guidelines /ceftriakson, ciprofloxacin and metronidazole in full doses (4). Chest $X$ ray showed two rounded $4 \times 3 \mathrm{~cm}$ (tumor-like) opacity in the middle and lower zone of the right lung (Figure 1(A)). On the third day of hospitalization, she was complaining about irregular heartbeats, ECG showed atrial fibrillation with chamber response of 140/min. Amiodarone, ACE inhibitors, digoxin, loop diuretics and beta blockers were included (1). Echocardiography: ejection fraction around $65-70 \%$. The patient was introduced to intensive IV loop diuretic therapy (1). After second and fifth day, chest X ray was performed (Figure 1 (B), Figure 1 (C)).). In order to confirm the presence of fluid in little incisura, computer tomography $(\mathrm{CT})$ reaffirmed phantom tumor of the lung (Figure 1 (D)).

\section{DISCUSSION}

The presented case experienced an acute exacerbation of congestive heart failure masked with pneumonia. After successful treatment of pneumonia, control chest $\mathrm{X}$ ray discovered characteristic posteroanterior radiographic phantom lung tumor, right-sided, well delineated pulmonary mass with smooth margins. The established presence of fluid in the large pleural cavity makes for the easiest diagnosis of phantom tumor. With adequate rapid resolution of the pneumonia and simple method of chest $\mathrm{X}$ ray pseudotumor of the lung was revealed and successfully managed with loop diuretics after patient felt relief. The diagnosis of phantom tumor is facilitated when there is evidence of fluid in the large pleural cavity. The localization of phantom tumor is not necessarily in the horizontal fissure to the right; it can also be less often located to the left, or nearer to the mediastinum $(5,6)$. The radiological appearance of the phantom tumor may vary, in relation to the volume of septated liquid and its location $(6,7)$. It usually shows as a homogenous spherical or elliptical opacity at the horizontal fissures, with clearly marked boundaries (6). Lateral chest X-ray could be significant for the enhanced localization of the lesion. Following the procedure of intravenous infusion of potent diuretics, radiological resolution can be observed in less than 24 hours. Injury recurrence may appear in the cases of subsequent cardiac decompensations.

In several patient's chest $X$ rays revealed intermittent appearance of the similar tumor-like shadows in the same region of the right lobe during an acute exacerbation of congestive heart failure confirming that phantom tumors can recur during episodes of cardiac decompensation (Figure D) $(6,7,8)$.

\section{CONCLUSION}

This case confirms efficacy of the conservative medical treatment (loop diuretics) of the localized interlobar effusion in congestive heart failure. The possibility of phantom lung tumor should be considered and excluded in any patient presenting with congestive heart failure and an apparent lung mass on a Chest X ray. Finally, it is necessary to highlight the importance of recognizing this condition in order to avoid needless, costly and potentially harmful errors in diagnosis and treatment.

\section{DECLARATION OF INTEREST}

The authors declare that there are no conflicts of interest.

\section{Licensing}

This work is licensed under a Creative Commons Attribution 4.0 International (CC BY 4.0) License.

\title{
Sažetak
}

\section{FANTOM TUMOR PLUĆA KOD PACIJENATA SA PNEUMONIJOM}

\author{
Mulić Mersudin, ${ }^{1}$ Biljana Lazovic, ${ }^{2}$ Detanac S. Džemail, ${ }^{3}$ Detanac A. Dženana, ${ }^{3}$ Milić Rade, ${ }^{4}$ Žugič Vladimir ${ }^{5}$ \\ ${ }^{1}$ State university Novi Pazar, Novi Pazar, Serbia \\ ${ }^{2}$ University clinical center "Zemun", Belgrade, Pulmonary Ward, Serbia \\ ${ }^{3}$ General hospital Novi Pazar, Novi Pazar, Serbia \\ ${ }^{4}$ Military medical academy, Belgrade, Serbia \\ ${ }^{5}$ Clinic for lung disease, Clinical Center of Serbia, School of medicine, Belgrade, Serbia
}

Uvod: Lokalizovani interlobarni izlivi kod kongestivnog srčanog zastoja (fantomski ili nestajući tumori pluća) su retki, ali široko priznati entiteti.
Prikaz slučaja: 80-godišnja žena sa progresivnom dispnejom tokom prethodna tri meseca, sa produktivnim kašljem. Lečena od hipertenzije, a implanti- 
ran joj je i pejsmejker zbog bradikardije. RTG snimak grudnog koša pokazao je pneumoniju sa desne strane sa visokim inflamatornim markerima. Nakon izlečenja upale pluća, otkriven je fantom tumor pluća koji nestaje nakon intenzivne terapije diureticima.

Zaključak: Dijagnozu fantomskog tumora treba razmotriti kao mogućnost kod svakog pacijenta sa kongestivnim zastojem srca i evidentiranom masom u plućima. Prikazani pacijent ranije nije imao znake kongestivnog zastoja srca, što ukazuje na to da se fantomski tumor može pojaviti kod bolesnika bez hroničnog kon-

\section{REFERENCES}

1. Lazović B, Stajić Z, Putniković B. Rapidly vanishing lung pseudotumor in a patient with acute bilateral bronchopneumonia. Vojnosanit Pregl. 2013; 70(9): 878-80.

2. Oliveira E., Manuel P., Alexandre J, Girno F. Phantom tumour of the lung. The Lancet. 2012; 380 (9858): 2028.

3. Stajic Z, Grdinic A, Lazovic B, Djuric P. Unexpected occurrence of cardiac tamponade following temporary pacemaker lead extraction. Herz. 2015; 40(4): 642-4.

4. Lazovic B, Blažic I, Zlatkovic-Svenda M, ĐurićV, Milić R, Zugic V. Severe pneumonia caused by antipsihotic drugs-what does not suit, the patient or the drug? Sanamed. 2018; 13(3): 307-10.

\section{Correspondence to/Autor za korespondenciju}

Biljana Lazovic

University clinical center "Zemun”, Belgrade, Serbia

Vukova 9, Zemun, 11070 Belgrade

Self phone +38162212040

Fax +3812141569

lazovic.biljana@gmail.com gestivnog popuštanja srca. Iako pouzdana dijagnostika fantomskog tumora upotrebom raznih vidova radiološke dijagnostike kod pacijenata bez kongestivnog zastoja srca može biti prilično izazovna, takva mogućnost se mora uzeti u obzir kod pacijenta sa masom u plućima u velikoj incizuri pluća. Zbog porasta broja gerijatrijske populacije i kasnijeg javljanja kongestivnog popuštanja srca, može se očekivati porast učestalosti fantom tumora pluća.

Ključne reči: kongestivno popuštanje srca, diuretici petlje, fantom tumori.

5. Lazović B, Agić A, Zlatković Švenda M, Blažić I, Andrejević V, Janeski N, Milić R, Žugić V. Pleural effusion mimicking vanishing phantom tumor of the lung - case report. Medical data. 2018; 10(2): 107-9.

6. Sarudis S, Karlsson A, Bibac D, Nyman J, Bäck A. Evaluation of deformable image registration accuracy for CT images of the thorax region. Phys Med. 2019; 57:191-9.

7. Daiki Akagaki D, Oba Tsaharu Nakano M, Haraguchi NG, Ohbuchi A, Ohshima H, Michihide Nishihara M, et al. Vanishing Tumor in the Right Pulmonary Apex: A Ghost on the Roof. Arch Cardiovasc Imaging. 2015; 3(3): e33809A.

8. Argan O, Ural D. Phantom tumor of the lung in heart failure patient. Turk J Emerg Med. 2017; 17(3): 121-2. 